УДК 13

\author{
ІВАН ЗАГРІЙЧУК \\ доктор філософських наук, професор, \\ Український державний університет залізничного транспорту \\ (м. Харків, Україна) \\ e-mail:zagrij@yahoo.com, ORCID:0000-0002-0319-3675
}

\title{
ФІЛОСОФІЯ ДОСОКРАТИКІВ: ВИТОКИ СИСТЕМНОГО МИСЛЕННЯ
}

Актуальність заявленої проблеми пов'язана зі змінами, які відбулись останнім часом як в методології пізнання, так і в сфері функціонування інформації, що має безпосереднє відношення до широкого впровадження електронних та Інтернет технологій в усі галузі наукового та суспільного життя. Результатом зберігання та передачі інформації на електронних носіях стала поява так званого «калейдоскопічного мислення», яке є антиподом системного. Саме тому виникає потреба в своєрідній реабілітації системного мислення, витоки якого ми віднаходимо вже у досократиків. В статті аналізуються філософські вчення досократиків 3 метою виявлення в них витоків раціонального мислення. Досліджуються шляхи, на яких античними мислителями були отримані перші результати системного осмислення світу, як світу цілісного, єдиного у своєму розмаїтті. Починаючи з Фалеса, в античній філософії відбуваються пошуки першопочатку, які були викликані потребою людини знати світ як цілісне утворення. Чисто інтуїтивно перші філософи відчували, що осмислити світ таким можливо лише виявивши єдину основу, з якої можна вивести усе його розмаїття. Лише за такої умови світ вдається представити упорядкованим, як космос. В дослідженні широко використовуються філософські тексти Аристотеля та Гегеля, а також наших сучасників, коментаторів творчості досократиків. Де це доречно, аналіз супроводжується фактами сьогоднішнього життя, які покликані підтвердити глибокі догадки наших попередників. Крім філософських міркувань Фалеса в статті аналізуються вчення Анаксімандра, Анаксімена, Піфагора, Зенона. Виправданням звернення до філософських початків $з$ метою віднайти там джерела системного мислення $є$ визнання того факту, що формування глибокого, по-справжньому теоретичного мислення найкраще здійснюється через осмислення проблем в історико-філософському контексті.

Ключові слова: система; поняття; цілісність; світ; раціональність; першопочаток; протиріччя

Постановка проблеми. Чого історія вчить? I чи вчить вона взагалі? Адже не лише на рівні гумору, але й в теоретичних працях зустрічаємо висловлювання на штиб: історія вчить тому, що вона нічому не вчить. Опустимо міркування про пластичність мови, їі нестрогість у багатьох випадках, полісемантику слів і ми побачимо, що попри усі застереження, ставлення до історії містить проблему. Це стосується не лише історії громадянської, але й історії мислення.

Будь-яка історія не може бути рецептом для вирішення сучасних проблем. I все ж, вона дечому та навчає, особливо тих, хто ставиться до неї творчо, використовує аналіз минулих успіхів і поразок як джерело досвіду. Досвіду, який безпосередньо не може бути застосований в нових умовах, тим не менш складає 
духовний багаж, що містить цілий набір можливих варіантів вирішення проблем. Іншими словами, будь-яка історія, в тому числі й історія мислення, може бути засобом розвитку та вдосконалення, а значить, навчителькою. Тільки $є$ одна проблема - вона не повинна сприйматись безпосередньо, а вимагає аналізу, або, іншими словами, повинна бути засвоєна розумом, а значить сприйнята опосередковано, через міркування.

Мета дослідження та аналіз публікацій. В контексті вище сказаного не зайвим буде звернення до світанкової доби розвитку філософії, коли тільки пробивались паростки змістовного системного мислення. Аналізуючи давню філософію, порівнюючи грецький дух зі східною філософією, Гегель вбачав історичні заслуги греків у тому, що «думка, яка розквітла там, ще більше звужує багатство подробиць, рівно як і східну колосальність, і зводить їх до простої душі, котра, однак, стає всередині себе джерелом багатства ідеального світу, більш величного світу думки» (Гегель, 2001, с. 189).

В такому підході до історії мислення міститься висока оцінка ролі узагальнень в осягненні світу, де узагальнення є операцією узгодження в рамках поняття «колосальних подробиць» за критерієм спільної суттєвої ознаки чи ознак. По суті це $є$ становленням мислення, як логіки, а якщо точніше, теоретичного мислення. «Думати - значить намагатися схопити через різноманіття аспектів будь-якої речі те, що може бути зрозуміле всім, а потім скорочувати це розуміння навколо утвореного поняття єдності, яке й буде їх логосом» (Хлєбніков Г., Степанов В., Глущенко Ю., 2019, с. 88).

Істинне, теоретичне мислення не дається людині від народження. Воно $є$ результатом освіти, вправ, тренування. I немає кращого способу його формування, як вивчення історії мислення, або, іншими словами, історії філософії.

В теоретичному або системному мисленні думки приведені «до ладу», упорядковані, а значить виведені одна 3 одної, становлять систему. Вони послідовні, не суперечать одна другій. Правда, тут необхідно зробити уточнення. Коли ми говоримо про несуперечність мислення, то маємо на увазі не протиріччя, яке $є$ джерелом розвитку, а про ту суперечність, яка $є$ ознакою недбалості мислення.

Якщо, як сказано вище, кращим способом формування теоретичного, а значить, системного мислення є вивчення історії філософії, то звернення до джерел є більш, ніж виправданим. Давні філософські вчення цікаві та повчальні тим, що в них відчувається биття думки. В подальших філософських міркуваннях 
досягнуте попередниками часто стає загальним місцем, чимось загальноприйнятим. А потім буває так, що й нехтується.

Уже у досократиків, нехай ще наївно, до кінця не усвідомлено, але містяться потуги дійти до основи, як передумови теоретичного, системного мислення. Сьогодні ж, маючи в минулому колосальні досягнення в цій царині, можна зустріти протилежні судження, які системність і логічність якщо й не заперечують, то все ж намагаються звузити. Так, наприклад, загальним місцем постмодерну як новітнього способу мислення $є$ «скепсис по відношенню до ідеї первородства» (Малахов В. С., 1998, с. 324), що означає відмову від виведення знання, виходячи $з$ певної основи. Останне приводить до порушення цілісності знання, його системності.

На сьогодні праць, присвячених філософії досократиків, практично не виходить. I тому, не дивлячись на деякі фундаментальні праці попередників (Богомолов А. С., 1985, с. 73; Асмус В. Ф., 1999, с. 544; Лурье С. Я., 1970, с. 664; Мамардашвили М. К., 2009, с. 248; Чанышев А. Н., 1981, с. 374), які здебільшого $\epsilon$ навчальними курсами, $є$ необхідність актуалізувати ідеї системного мислення, які мають місце в античній філософії. Це стає особливо актуальним в умовах, коли розвиток Інтернету та цифрових засобів масової інформації уже призвів до формування «калейдоскопічного мислення», яке до певної міри є антиподом системному.

Усвідомлюючи протиріччя сучасної доби, ставимо собі за мету дослідження проявів системного мислення на ранніх етапах становлення філософії, які $з$ висоти сьогоднішнього рівня розвитку науки можуть бути усвідомлені так, як ніколи раніше. Адже тільки завдяки знанню предмета на етапі його зрілості можна усвідомити те, що на початку його становлення існувало лише у формі натяку.

Виклад основного матеріалу дослідження. Зі свого зародження філософія прагнула пізнати найглибші основи буття. Це було продиктовано потребою знати світ як ціле, осягнути його як цілісність. Пізнати його саме таким означало зрозуміти розмаїте буття в його єдності. Справжня ж єдність завжди $\epsilon$ структурованою й існує як система, в якій елементи, що ії складають, пов'язані між собою необхідним чином. Такою система може бути за однієї умови - коли усі їі елементи виведені із єдиної основи. Власне саме із-за такої потреби, можливо до кінця неусвідомленої першими філософами, відбувався пошук першопочатку, прийняття якого дозволяло представити і зрозуміти світ як певний порядок, як космос. 
Оскільки початки філософування сприймаються нами як дитинство роду людського, то сказане вище не буде зайвим підкріпити спостереженнями, які зустрічаються в дитячому віці сьогодні. Що означають дитячі питання до дорослих, в яких вони цікавляться своїм походженням? Хіба питання малюка: звідки я? не є до кінця не усвідомленим бажанням не просто знати світ, в який його привели батьки без його згоди на це, а саме дійти до його основ? На поверхні воно виглядає як проста допитливість, але, як потім виявиться, це питання постане як проблема життя і смерті, як проблема практична, як смисложиттєва проблема.

Питання первоначала проявляється по-різному на рівні буденного світогляду, який завше містить у собі інтенції до трансформації у світогляд теоретичний. Прикладом ще одного способу пізнати основу світу є мандри степом нашого Кобзаря, який ще хлопчиком ходив дивитись стовпи, які підпирають небо. Ці та інші приклади щоденного життя свідчать про практичне походження філософських, так званих «вічних проблем».

Саме 3 такої практичної потреби, яка ставала теоретичним пошуком, виходили перші філософи, які ставили перед собою питання, що лежить в основі світу. Ось, наприклад, Фалес вважав основою світу воду. Звідки могла прийти в голову така ідея? Про це вже багато сказано в історико-філософських працях. Не має сенсу повторювати все в деталях, але на дечому слід акцентувати увагу, виходячи $з$ контексту нашої теми.

Вода у філософії Фалеса є одночасно природною стихією і принципом його філософського світогляду. 3 одного боку, вона $є$ матеріальним субстратом, 3 іншого, перетворюючись через згущення і випаровування, вона стає іншою, не водою, хоч залишається в усіх перетвореннях тією ж водою, але вже як принцип єдності всього існуючого. Власне ми тут бачимо, що вода, будучи матеріальним субстратом, його іменем, одночасно містить тенденцію до відриву від іiі матеріальної основи і перетворення в поняття. Вода, як поняття, уже презентує не лише воду як елемент, як одну із стихій, а виступає як збірне поняття для цілої низки ії видозмінених форм.

Якщо у Фалеса концепт води ще виступає в двох іпостасях, то в Анаксімандра нескінченне або апейрон уже не має чуттєвої визначеності. Він $є$ щось невизначене, звідки все виникає і куди все повертається після закінчення терміну свого явного існування. Апейрон $є$ абсолютною безперервністю. Ця безперервність постійно творить із себе скінчені речі, що $є$ покладанням відмінностей, виділенням із себе окремого існування. На відміну від 
невизначеного, чим є апейрон, виділені із нього окремі існування уже в силу того, що вони виділені, набувають статусу визначених, таких що мають межу, означені в просторі, відмінні від інших. Межа відділяє одне, виділене із невизначеного нескінченного, від такого ж іншого, покладеного тим же нескінченним. Правда, як фіксують доксографи, у Анаксімандра нічого власне нового не виникає в процесі діяльності апейрона, адже все, що з’являється, уже містилось в ньому раніше.

Про що це свідчить? Виявляється, що походження розмаїтих форм існування iз апейрона, не є власне породженням, тобто таким, що відбувається необхідним чином, а є всього лише слідуванням. Але не всяке слідування містить в собі причинно-наслідковий зв’язок. А якщо так, то виділення окремого із невизначеного апейрона не $\epsilon$, строго кажучи, необхідним. Відповідно, осягнення цілісності світу Анаксімандром назвати системним можна лише умовно. Оцінюючи таке розуміння світу, Гегель підкреслює, що «це «походження» не містить в собі ніякої необхідності, ніякої думки, ніякого поняття» (Гегель, 2001, с. 214). Сказано, очевидно, строго, але, за великим рахунком, вірно.

Дозволимо собі проінтерпретувати відмінність «слідування» від «породження» на прикладах нашого щоденного життя. Щоб бути ближчим до термінології Гегеля, зазначимо, що «слідування» i «походження» мало чим відрізняються між собою, але суттєво від значення терміну «породження». Ходити і слідувати не означає породжувати. Події, що слідують одна за одною, не завжди причинно обумовлені, пов'язані між собою необхідним чином. Ототожнення слідування 3 породженням часто лежить в основі забобонів. Наприклад, відоме усім упередження про те, що коли дорогу перебігла чорна кішка, то чекай поразки у справах. Або, стійке переконання багатьох у тому, що погано, як твою дорогу перейде людина з порожнім відром і т. д.

Оскільки мова йде про системність мислення, то слід зауважити, що системи $\epsilon$ різні за своїм обсягом та змістом. Коли ми говоримо про рідних братів і сестер, то нерозривність їхніх родинних зв’язків пов'язана 3 походженням від одних батьків. В соціальному плані розірвати ці зв’язки можливо, але в біологічному сенсі такого розриву не здійснити. Як фізичні риси, так і можливі спадкові хвороби залишаться при них навіть при соціальному відчуженні. Трудовий колектив також $є$ певною системою, допоки він існує. Але кожен окремий працівник може звільнитись і перестане бути його одиницею, що пов’язана системою трудових відносин. Натовп, юрба системними не є. Існують також «рукотворні» економічні, політичні, технічні та інші системи. Їхньою спільною 
рисою $\epsilon$ те, що всі вони мають спільну основу свого існування, яка може виступати також як мета.

Наведені приклади реального практичного життя містять у собі необхідність спільної логіки, мислення, яке, для того щоб бути системним, вимагає єдиного начала, виведення з нього всього розмаїття реальних системних цілісностей. Без цього теоретичне, а значить, істинне розуміння предмета зацікавлення неможливе.

Задачу понятійного, тобто системного мислення вирішує філософія в найбільш узагальненому вигляді. Спроби усвідомлення мислення в поняттях були зроблені уже в творчості перших мислителів, яких прийнято називати натурфілософами.

Анаксімен твердив, що первоначало існує у формі повітря, яке нібито, на відміну від невизначеності апейрона $\epsilon$ визначеним. Гегель, оцінюючи первоначало Анаксімена, вважав, що повітря представляє собою «щось, подібне до душі» (Гегель, 2001, с. С. 216). Тут ми маємо дещо інший поворот у розумінні основи існування. Якщо згадати Фалеса з його твердженням, що й магніт має душу, — твердження, яке він допустив, щоб пояснити рух у світі, основою якого є вода, - то Анаксімен, прийдеться визнати, виходячи з попередніх міркувань, по суті зробив первоначало рухомим. Те, що було у Фалеса розведеним, у Анаксімена стало єдиним. Він ототожнив рухоме і причину руху. Завдяки цьому уявлення про світ в його філософії здається нам більш системним.

Звичайно, це досить умовно, адже ще Аристотель у своій «Метафізиці» підкреслював, що більшість філософів, котрі жили до нього, «вважали началом всього одні лише матеріальні начала» (Аристотель, 1976, с. 71). Тим не менш, ми вважаємо, що тенденції, які проглядаються в творчості перших філософів, свідчать про їх прагнення, нехай до кінця й не усвідомлені, вийти за межі матеріального, чуттєво даного, виразити первоначало у формі думки, поняття. Про це говорить і Гегель, зауважуючи, що філософи, про яких йде мова, «не знають, що те, що вони висловлюють, є сутністю, яка належить сфері свідомості» (Гегель, 2001, с. 218). Власне, вже й Аристотель, змушений був визнати, що, не дивлячись на матеріальний характер первоначал своїх попередників, «в міру їх просування в цьому напрямку сама суть справи вказувала їм шлях і заставляла їх шукати далі» (Аристотель, 1976, с, С. 72).

Часто прикладом «нематеріальності» начала вважають число Піфагора. Однак, це не зовсім так. Як зазначає О. С. Богомолов, «спочатку піфагорійці формулюють сугубо конкретне, «фізичне» розуміння числа: числа суть протяжні 
«речі», з яких складаються предмети чуттєвого світу. Вони - «начало і елемент» всього сущого в сенсі іонійської філософії» [Богомолов, 1985, с, 73). Тільки потім, під впливом критики з боку елейців, первісне формулювання було трансформовано і набуло вигляду — не «речі суть числа», а «речі подібні до чисел». Та навіть таке визначення ще не робить число в повному сенсі ідеєю, яка тільки й може виступити тим єдиним, що робить наше пізнання зв'язаним. Саме 3 цієї причини Аристотель й зауважує, що, намагаючись узгодити частини світобудови між собою, привести їх у гармонію, піфагорійці, коли у них виявлялась прогалина, прагнули заповнити іiі, «щоб усе вчення було зв'язаним» (Аристотель, 1976, с, 76).

Аристотель, як історик філософії, звертає увагу на те, що вже Платон, користуючись поняттям числа, вважав його серединним між речами, що сприймаються чуттями, і ейдосами. Числа - це «проміжні математичні предмети, що відрізняються від тих, що сприймаються чуттями, тим, що вони вічні і нерухомі, а від ейдосів - тим, що є багато однакових таких предметів, в той час як кожний ейдос сам по собі тільки один» (Аристотель, 1976, 79). Це дало право Гегелю сказати, що «піфагорійська філософія представляє собою перехід від реалістичної філософії до інтелектуальної» (Гегель, 2001, с, 230).

Таким чином, ми спостерігаємо, що Піфагор, як і його попередники, прагнучи системно осмислити світ, навіть, покладаючи в його основу чуттєво сприймані речі, неминуче виходили за межі цих чуттєво сприйманих речей. Намагаючись пізнати світ мінливих предметів, мислителі цієї доби через наївне сприйняття розвитку все ж зміни визнавали, хоч і виражали їх не зовсім коректно. Як Аристотель, так і Гегель, аналізуючи вчення названих філософів, зазначали, що перетворення первоначала у них не носить необхідного характеру. Це означає, що системність їхнього мислення, яка реалізується ними в творчості, ще не досягла необхідної зрілості.

В принципі інакше і не могло бути. Адже перетворення одного природного елемента в інший, чи навіть видозміна елемента, все одно здійснювалась як перехід в інший природний елемент. На рівні буття все саме так і відбувається. Це означає, що поняття ще не визріло в чисту мислительну форму, що первоначало, як сутність, ще не відноситься до самого себе, а тільки до іншого, до зовнішнього. А тому Гегель, виявляючи інтенцію цих вчень, зазначає, що «найближчий подальший погляд повинен би полягати в тому, щоб абсолютне розумілось не як природна форма, а як форма визначення думки» (Гегель, 2001, c, 231). 
Мова, таким чином, йде про понятійне мислення, яке тільки і може бути системним. Але «для того, щоби щось мало форму поняття, воно повинно в самому собі, як визначене, співвідноситися зі своєю протилежністю, як, наприклад, позитивне і негативне» (Гегель, 2001, с, 232).

Якщо розглядати системність, як цілісність, то Піфагор не лише в теорії прагнув органічної узгодженості між частинами цілого через математичне число, але й намагався бути, та власне й був, учителем народу в Греції. Знову ж таки, як зазначає Гегель, в особі Піфагора Греція вперше отримала вчителя, який «ставив метою цілісність, здійснював принцип через розвиток розуму, чуття і волі» (Гегель, 2001, с, 227). Будучи математиком, філософом, громадським діячем, Піфагор, таким чином прагнув цілісності не лише в теорії, але й у житті. Власне це була позиція, яку ми сьогодні кваліфікуємо як єдність теорії і практики. О. С. Богомолов 3 цього приводу зазначає, що прагнення Піфагора знайти «начало» всього сущого було пов’язано з його бажанням «пояснити світ, людину і її місце в космосі і соціумі» (Богомолов, 1985, с, 74).

Цікавою і повчальною з цього боку є практична філософія Піфагора, яка виступає в нього як облаштування морального життя і $є$, по суті, реалізацією в практичній сфері його філософії числа. Математичні предмети, якими є числа, як нам відомо, знаходяться між тими предметами, які сприймаються чуттями, i тими, які існують у формі ейдосів. Простіше кажучи, числа у Піфагора уже не зовсім є предметами чуттєвого сприйняття, але разом 3 тим ще не $\epsilon$ «чистим» поняттям. Власне такою не вивершеною, не закінченою, не всезагальною видається нам і громадська діяльність Піфагора. Союз, який отримав назву піфагорійського, був закритим, його суспільна діяльність була обмеженою колом посвячених. Це означає, що його вплив на суспільство не був всезагальним, а діяльність союзу, як і його засновника, не була суспільною за своїм поняттям. Тобто це об' єднання не мало того впливу на суспільство, яке воно могло і мусило мати. Розглядаючи зв'язок теорії числа Піфагора з його практичною філософією, яка, як ми уже зазначали, виступає як облаштування морального життя, Гегель констатував, що «подібно до того як число є чимось проміжним між чуттєвістю і поняттям, так і піфагорійський союз є щось проміжне між всезагальною дійсною моральністю і точкою зору моралі, відповідно до якої одинична людина саме в якості одиничної повинна турбуватись про свою мораль, так що остання перестає бути всезагальним духом» (Гегель, 2001, с, 252).

Розглянуті нами філософські вчення містять, звичайно, спроби вийти за межі чуттєво сприйманих речей, але в тій чи іншій мірі вони все ж оперують 
принципами у формі матеріальних речей. Навіть повітря або дихання Анаксімена, число Піфагора в намаганні надати їм статусу поняття, «чистої» думки не стали такими по суті. Про це говорили і підкреслювали, як Аристотель, так і Гегель. I лише філософія елейців демонструє нам вихід за межі чуттєво сприйманих речей, заглиблення в сутність настільки, що, довіряючи тільки розуму, вони найшли в собі мужність заперечити існування руху. Звичайно, мова не йшла про невизнання руху на рівні чуттєвого сприйняття. Просто сприйняття руху чуттями виявилось недостатнім. Пізнання істини світу, його єдності вимагало пізнання основи мінливості. I хоч вирішити цю проблему елейцям не вдалось, однак їхня філософія свідчить про фіксацію уваги виключно на мисленні. Це дало підстави Гегелю визнати, що елейці здійснили величезний крок уперед у порівнянні зі своїми попередниками і прийшли до «чистої думки» і що «думка, власне кажучи, лише в елейській школі виступила, таким чином, вільно і самостійно» (Гегель, 2001, с, 257).

У Зенона єдність, про яку мова, мертва, нерухома. Тим не менш, нерухоме єдине $є$ у нього істинним, оскільки мінливе, на його думку, істиною бути не може. Але так потрактована істина суперечить мінливим скінченим речам. На противагу рухливим предметам матеріального світу незмінна сутність істинного буття залишається абстрактною. Вона тотожна з собою і знаходиться в єдності тільки 3 собою. Тоді як «скінчене, як обмежене, повинно мати свою основу в нескінченому» (Гегель, 2001, с, 259).

Спробуємо проінтерпретувати сказане Зеноном і оцінене критично Гегелем 3 позицій сьогоднішнього розуміння руху, використовуючи диференціальне та інтегральне обчислення. Міркування елейця стосовно неможливості руху 3 позицій істинного пізнання, якщо взяти його знамениту апорію: «Стріла, яка летить, стоїть на місці», будуються на диференціюванні відстані, в результаті якого рано чи пізно стріла опиниться в точці і стане нерухомою. Чи так це насправді?

Чуттєве сприйняття рух фіксує, але вже буденна свідомість не задовольняється тільки сприйняттям i, спираючись на формальну логіку та використовуючи арифметику, сумуючи стани спокою, отримує спокій, відірваний від руху. Але чому тоді ми переконані в тому, що рух абсолютний, а спокій відносний?

Бути відносним - означає відноситись до чогось, залежати від цього чогось, бути пов'язаним з ним. Виявляється, що спокій не є самостійним, що він залежить 
від руху, а якщо так, то його визначення можливе через свою протилежність, тобто через рух.

Перш ніж визначити рух через спокій, а спокій через рух, показати їх пов’язаність і взаємну негацію, звернемось до вищої математики, яка якраз i займається диференціальним та інтегральним обчисленням. Результатом диференціювання, як виявляється, є нескінченно мала величина, що означає, що вона прагне до нуля, але ніколи його не досягає. В математиці ця величина називається похибкою i ii iгнорують в диференціальних та інтегральних обчисленнях, так як вона настільки, як вважається, мала, що не впливає на результат обчислення.

Виходячи із сказаного, можемо стверджувати, що спокій — це не відсутність руху, а нескінченно мала його величина. Ми можемо проігнорувати його i прирівняти до нуля, як ми це робимо в диференціальних та інтегральних обчисленнях А це означає, що істинне пізнання світу як цілісності вимагає системного, діалектичного мислення, мислення, яке вбирає в себе всю розмаїтість світу i виражає цю розмаїтість в поняттях, які чуттєво не сприймаються. Врешті-решт, поняття внутрішньо суперечливі i цю суперечливість можна пізнати тільки розумом. Як зазначає Гегель: «я можу ділити матерію до нескінченності, але я це лише — можу — я ії в дійсності не ділю до нескінченності» (Гегель, 2001, с, 279).

I ще про системність мислення у виконанні Гегеля. «Ділимість, як можливість, є всезагальне; в ньому покладені як безперервність, так i негативність, або точка, але покладені як моменти, а не як самі по собі сущі» (Гегель, 2001, с, 279).

Висновки. Аналіз перших філософських вчень показує, що всі зусилля 3 пошуку первоначала були пов’язані з потребою зрозуміти мінливий світ як цілісність. Спроби розв’язати цю проблему, поклавши в основу матеріальний елемент, чи природну стихію, з необхідністю вели до виходу за межі чуттєво сприйманих речей і занурення в стихію «чистого» мислення, яке існує як поняття. А поняття, як відомо, форма мислення. Вміння рухатись в стихії «чистого», змістовного, а не порожнього, чи навіть пустопорожнього мислення, - означає мислити поняттєво, мислити системно. Витоки такого мислення містяться вже у філософських вченнях досократиків, знайомство з якими є важливим історикофілософським підгрунтям сучасного теоретичного осмислення світу. 


\section{СПИСОК ВИКОРИСТАНИХ ДЖЕРЕЛ}

Аристотель. Метафизика // Сочинения в четырех томах. Т. 1. - М.: Мысль, 1976. - С. 63-367. Богомолов А. С. Античная философия. - М.: Изд-во МГУ, 1985. - 367 с.

Гегель Г. В. Ф. Лекции по истории философии. Книга первая. - СПб: Наука, 2001. - 350 с.

Малахов В. С. Постмодернизм, постмодерн // Современная западная философия. - М., 1998. С. 324-326.

Хлєбніков Г., Степанов В., Глущенко Ю. Платонівська рефлексія філософії. - Вісник Донбаського державного педагогічного університету. Випуск 1 (10). Серія: Соціальнофілософськкі проблеми розвитку людини і суспільства. - Слов'янськ, 2019. - С. 84-96.

Асмус В. Ф. Античная философия. - М.: Высшая школа, 1999. - 544 с.

Лурье С. Я. Демокрит: Тексты, перевод, исследования. - М.: Наука, 1970. — 664 с.

Мамардашвили М. К. Лекции по античной философии. - М.: Прогресс-Традиция. Фонд Мераба Мамардашвили, 2009. - 248 с.

Чанышев А. Н. Курс лекций по древней философии. - М.: Высшая школа, 1981. — 374 с.

ИВАН ЗАГРИЙЧУК доктор философских наук, профессор Украинский государственный университет железнодорожного транспорта (2. Харьков, Украина) e-mail:zagrij@yahoo.com, ORCID:0000-0002-0319-3675

\section{ФИЛОСОФИЯ ДОСОКРАТИКОВ: ИСТОКИ СИСТЕМНОГО МЫШЛЕНИЯ}

Актуальность заявленной проблемы связана с изменениями, которые произошли последнее время как в методологии познания, так и в сфере функционирования информации, что имеет непосредственное отношение к широкому внедрению электронных и Интернет технологий во все отрасли научной и общественной жизни. Результатом хранения и передачи информации на электронных носителях стало появление так называемого «калейдоскопического мышления», которое является антиподом системного. Именно поэтому возникает потребность в своеобразной реабилитации системного мышления, истоки которого мы находим уже у досократиков. В статье анализируются философские учения досократиков с целью выявления в них истоков рационального мышления. Исследуются пути, на которых античными мыслителями были получены первые результаты системного осмысления мира, как мира целостного, единого в своем разнообразии. Начиная с Фалеса, в античной философии происходят поиски первоначала, которые были вызваны потребностью человека знать мир как целостное образование. Чисто интуитивно первые философы ощущали, что осмыслить мир таким возможно только обнаружив единое основание, из которого можно вывести все его разнообразие. Только при таком условии мир получиться представить упорядоченным, как космос. В исследовании широко используются философские тексты Аристотеля и Гегеля, а также наших современников, комментаторов творчества досократиков. Где это уместно, анализ сопровождается фактами сегодняшней жизни, которые призвании подтвердить глубокие догадки наших предшественников. Кроме философских размышлений Фалеса в статье анализируются учения Анаксимандра, Анаксимена, Пифагора. Зенона. Оправданием 
обращения к философским началам с целью обнаружить там истоки системного мышления является признание того факта, что формирование глубокого, по-настоящему теоретического мышления лучше всего осуществляется через осмысление проблем в историко-философском контексте.

Ключевые слова: система; понятие; целостность; мир; рациональность; первоначало; противоречие

IVAN ZAGRIICHUK

Doctor of Philosophical Sciences, Professor, Ukrainian state university of railway transport (Kharkiv, Ukraine) e-mail:zagrij@yahoo.com,ORCID:0000-0002-0319-3675

\section{PHILOSOPHY OF PRE-SOCRATIC PHILOSOPHERS: THE ORIGIN OF SYSTEMATIC THINKING}

Introduction. The formation of systematic thinking is impossible without learning the history of its formation. Systematicity is a sign of theoretical thinking. And theoretical as a category of scientific thinking is a conceptual history, taken at its most momentous moments. Quite often the theoretical corrects the historical course of events and processes that can be interpreted, but this correction is based on the logic of the historical process itself. In other words, the theoretical view on the world is freed from insignificant moments of empirical history and captures solely its logic, represents history in concepts as well as forms of pure thinking. Purpose. This truth, achieved through intellectual suffering of its forerunners, turned out to be a little dimmed recently. A common place of postmodern as the newest way of thinking is "skepticism about the idea of primogeniture" (Malakhov, 1998, p. 324) and such attitude to the history of the formation of theoretical thinking means the rejection of leading knowledge coming out from a certain basis. This leads to disruption of its systematic nature. Nowadays little attention is paid to this problem in philosophical literature. The problems of systematic thinking are examined mostly in the educational literature. Paying attention to the particular relevance of critical thinking in the face of the rapid development of the internet and digital mass media there is a necessity to update the ideas of systematic thinking that emerged in the ancient philosophy. This necessity is determined by the fact that the rapid development of digital technologies and the dynamics of modern life led to the wide expansion of so-called "kaleidoscope thinking" which to some extent is the antithesis of the systematic one. Being aware of the contradictions of modern times we aim to study the manifestations of systematic thinking on the early stages of the philosophy formation which can be realized from the height of today's level of science development as never before. Because it is only due to knowing the subject at the stage of its maturity one can realize what existed only in a form of a hint at the beginning of its formation. Results. Since its inception strived the philosophy after perceiving the deepest basics of being. It was dictated by the need to know the world as a whole, which parts are mutually agreed. To get to know the world this way meant to understand the diverse existence in its unity. True unity is always structured and exists as a system where the elements making it are connected in a necessary way. A system can be so under one condition - when all its elements are derived from a single basis. It is because of this necessity, presumably not completely realized by the first philosophers, the search of the origin has taken place, which acceptance has allowed to imagine and to understand the world as a certain order, as a cosmos. Thales considered water to be the basis of the world. Water in his philosophy is simultaneously an 
element of nature and a principle of philosophical world view. As a concept it not only presents water as an element, as one of the elements, but also acts as a collective concept for a number of its modified forms. Apeiron Anaximander has no sensual certainty. It is something indefinable, an absolute continuity. This continuity constantly creates finite things, which is generating differences, the detachment a separate existence from itself. Unlike the indeterminate, what is Apeiron, individual existences isolated from it, acquire the status of definite, as such that have boundaries, defined in space, different from others just due to the fact they are separated. But it turns out that extraction of various forms of existence from Apeiron is not a truly generation, that is, such that occurs in appropriate way, but is merely a succession. But not every succession contains a cause-and-effect relationship. Separation of an individual from an indefinite Apeiron is not strictly necessary. In this regard Hegel noted that "this "origin" contains no need, no thought, no concept" (Hegel, 2001, p. 214). Events following after each other are not always causally related, interconnected as necessary. Identification succession with generation is often the basis of prejudice. Anaximenes claimed the origin existing in the form of the air that "is something like a soul" (Hegel, 2001, p. 216). If Thales introduced the soul to "revive" the existence, Anaximenes sees the very basis of being in movement. What was separated by Thales becomes one by Anaximenes. He identified the moving and the cause of movement. Due to this the concept of the world in his philosophy seems to us being more systematic. The tendencies seen in the works of the first philosophers are evidence of their desire to go beyond the material, the sensually given, to express the origin in a form of a thought, of a concept. The Pythagorean number is often being considered as an example of "intangibility". But this is not quite true. Pythagorean numbers take an intermediate place between material objects perceived by the senses and eidos, which can be cognized only by the mind. This suggests that Pythagoras' philosophy "is a transition from a realistic philosophy to an intellectual one" (Hegel, 2001, p, 230). Being a mathematician, a philosopher, a public figure, Pythagoras sought for integrity not only in theory, but also in life. His practical philosophy acts as an arrangement of moral life and is in fact a realization of the philosophy of numbers in the practical. But both in philosophy his number is not yet in the form of pure concept, in the form of universal, and in practical life his influence on society has not been universal. The union called the Pythagorean was closed, its public activity was limited by a circle of devotees. The philosophy of the Eleatics demonstrates to us coming beyond the scopes of sensually perceived things, the immersion in the essence to that extent, that, trusting solely the mind, they have found the courage to deny the existence of the movement. The perception of the movement by the senses turned out to be insufficient. Getting to know the truth of the world, its unity required getting to know the basis of change. Although the Eleatic philosophers have not succeeded in solving this problem, their philosophy testifies the fixation of attention solely on thinking. This gave Hegel a reason to acknowledge that the Eleatics had taken a huge step ahead in comparison with their predecessors and had come to a "pure thought" and that "the thought, in fact, was made only in the Eleatic school, thus, free and independent» (Hegel, 2001, p, 257). The unity, about which Zenon is talking, is dead and static. He did not manage to explain the motion. Only Hegel did. The explanation for theoretical solution of the motion problem is the theory for differential and integral calculations. True knowledge of the world as a whole requires systematic, dialectical thinking, it means such mindset that absorbs all the diversity of the world and expresses this diversity in terms that are not perceives sensually. Conclusions. The analysis of the first philosophical doctrines demonstrates that all efforts to find the origin were connected with the necessity to understand the changing world as a whole. Attempts to solve this problem while considering a material element or a natural element as the base necessarily led to going beyond the scopes of sensually perceived things and immersing in the element of "pure" thinking that exists as a concept. And a concept is known to be a form of thinking. The ability to move in the element of "pure", meaningful, and not empty, or even shallow thinking, means to think conceptually, to think systematically. The origins of such thinking are already 
found in the philosophical teachings of the Pre-Socratics, acquaintance with which is an important historical and philosophical foundation of modern theoretical understanding of the world.

Key words: systemic thinking; integrity; world; rationality; origin; contradiction

\section{REFERENCES}

Aristotel. Metafizika (1976). Sochineniya v chetyrekh tomah. T. 1. M.: Mys1. P. 63-367.

Bogomolov A. S.(1985). Antichnaya filosofiya. - M.: Izd-vo MGU, 1985. 367 p.

Hegel G. V. F.(2001). Lektsii po istorii filosofii. Kniga pervaya. - SPb: Nauka. 350 p.

Malakhov V. S. (1998). Postmodernizm, postmodern. Sovremennaya zapadnaya filosofiya. M., P. 324-326.

Khliebnikov H., Stepanov V., Hlushchenko Yu. (2019). Platonivska refleksiia filosofii. Visnyk Donbaskoho derzhavnoho pedahohichnoho universytetu. Vypusk 1 (10). Seriia: Sotsialnofilosofskki problemy rozvytku liudyny i suspilstva. - Sloviansk. P. 84-96.

Asmus V. F. (1999). Antichnaya filosofiya. — M.: Vysshaya shkola. 544 p.

Lure S. Ya. (1970). Demokrit: Teksty, perevod, issledovaniya. - M.: Nauka, 1970. 664 p.

Mamardashvili M. K. (2009). Lektsii po antichnoi filosofii. — M.: Progress-Traditsiya. Fond Meraba Mamardashvili. 248 p.

Chanyshev A. N. (1981). Kurs lekcij po drevnej filosofii. — M.: Vysshaya shkola. 374 p.

\section{Надійшла до редакції 20.10.2019 р.}

